\title{
Taxonomical remarks on Allium yamadagensis Yıldırım \& Ekşi, (Amaryllidaceae) from Turkey
}

\author{
Emrah ŞİRIN ${ }^{* 1}$, Mehmet Cengiz KARAİSMAİLOĞLU ${ }^{2}$ \\ ORCID: : 0000-0003-3408-7186; 0000-0002-6856-2742 \\ ${ }^{1}$ Department of Biology, Faculty of Science, Selçuk University, 42125, Konya, Turkey \\ ${ }^{2}$ Department of Biology, Faculty of Arts and Sciences, Siirt University, 56500, Siirt, Turkey
}

\begin{abstract}
An evaluation was conducted of A. yamadagensis, which is a Critically Endangered (CR) species that is endemic to Turkey, comprising an analysis of its taxonomical, micromorphological, macromorphological, cytological and palynological features, in addition to its geographical distribution. Scanning Electron Microscopy was used to obtain seed and pollen surface microphotographs. The shape and sculpturing of the seed periclinal walls are convex and granulose. The shape of the pollen grains appears monocolpate, with polar and equatorial axes of $23.65 \pm 0.29$ and $14.92 \pm 0.33 \mu \mathrm{m}$, respectively. A. yamadagensis has a pollen ornamentation that is foveolate-microreticulate. Cytological analyses revealed that $A$. yamadagensis is diploid and has a chromosome number of $2 n=2 \mathrm{x}=16$.
\end{abstract}

Keywords: chromosome, cytology, morphology, palynology

Türkiye'den Allium yamadagensis Yıldırım ve Ekşi (Amaryllidaceae) üzerine taksonomik açıklamalar

\section{Özet}

Bu çalışma, Türkiye'den Kritik Tehlike Altındaki (CR) bir endemic tür olan A. yamadagensis'in coğrafi dağılımı ile birlikte taksonomik, makro ve mikro morfolojik, palinolojik ve sitolojik özelliklerin değerlendirilmesini rapor etmektedir. Tohumların ve polenin yüzey mikro fotoğrafları Taramalı Elektron Mikroskobu kullanılarak elde edildi. Tohum periklinal duvarları (şekil ve yontma) dışbükey ve granül. Polen taneleri, $23.65 \pm 0.29 \mu \mathrm{m}$ kutup eksenleri ve $14.92 \pm 0.33 \mu \mathrm{m}$ ekvator eksenleri ile tek kolpat şeklinde görünür. A. yamadagensis'in polen süslemesi foveolat-mikroretikülattır. Sitolojik araştırmalar, A. yamadagensis'in $2 n=2 \mathrm{x}=16$ kromozomlu diploid olduğunu ortaya çıkarmıştır.

Anahtar kelimeler: kromozom, morfoloji, palinoloji, sitoloji

\section{Introduction}

Within the family Amaryllidaceae, Allium L. is among the largest genera [1]. More species have been described since Linnaeus accepted the first 30 species, and now comprises over 920 [2]. In Turkey, there are now about 220 Allium taxa [3], which have been divided into 14 sections [4], comprising a significant portion of the southeastern Asian center of diversity for Allium [5].

A. yamadagensis is closely related to A. sintenisii Freyn, A. erzincanicum Özhatay \& Kandemir, A ekimianum Ekşi, Koyuncu \& Özkan, and A. asperiflorum Miscz. and all of them belong to section Allium [6].

Seed morphology provides useful systematic characters at various taxonomic levels in the genus Allium [7, 8, $9,10,11,12,13,14,15,16,17]$.

Chromosomes give important information about plant systematic. Particularly, the chromosome numbers in each cell, size of the chromosomes and centromere position are being studied [18].

\footnotetext{
${ }^{*}$ Corresponding author / Haberleşmeden sorumlu yazar: Tel.: +903322231881; Fax.: +903322231881; E-mail: emrahsirin@ selcuk.edu.tr

(C) Copyright 2021 by Biological Diversity and Conservation $\quad$ Received: 26.03.2021; $\quad$ Published: 15.08.2021 BioDiCon. 967-260321
} 
In this work, morphological (macro and micro), palynological, and cytological features of Allium yamadagensis in Turkey have been studied for the first time.

\section{Materials and methods}

Specimens were collected by the first author and were kept in the herbarium of the Science Faculty of Selçuk University (KNYA). At least ten seed and pollen for each species were dehydrated in alcohol series $(70 \%, 80 \%, 96 \%$ and $100 \%$ ) in SEM analyses for cleaning process. Seed and pollen were coated with gold under ZEISS EVO LS-10 model SEM high-vacuum mode for observing their surface. For the seed length and width 20-25 seeds were measured. Seed shape was recognized following overall plane or two-dimensional shape as standardized by [19]. The names of the different types of undulation followed the terminology as defined and adopted by [20]. In addition, the stereo microscope images of the seeds were photographed with the LEICA DFC295 digital camera attached to the LEICA S8AP0 microscope.

Karyological observations were made on mitotic metaphase cells of root-tips obtained from planted bulbs which were collected in natural habitats from Turkey. Root tips were pretreated in $\alpha$-monobromonaphthalene at $4^{\circ} \mathrm{C}$ overnight, washed with distilled water and fixed in Carnoy's solution (3:1 absolute ethanol: glacial acetic acid) for a minimum of $1 \mathrm{~h}$. The root tips were hydrolyzed for $10-12$ minutes in $1 \mathrm{~N} \mathrm{HCl}$ at $60^{\circ} \mathrm{C}$, stained using the standard Feulgen technique and squashes were prepared. Permanent slides were made by the liquid CO2 method (For chromosomal analyses the protocol of [21] was applied.

Collection address of the studied samples: Malatya, Hekimhan, summit of Yamadağ, stony places, $2545 \mathrm{~m}, 27$ July 2018, E. Şirin 740 (KNYA), in fruit.

\section{Results}

Allium yamadagensis Yıldırım \& Ekşi (2019: 31).

Type: TURKEY. Malatya: Hekimhan, Yama Mountain, summit, volcanic rocky slopes, 2570 m, 27 July $2015, H$. Ylldırım 3487 (holotype, EGE, isotypes, EGE, NGBB, ANK, HUB) (Figure 1).

Additionally, morphological characters are as follows: Scape cylindrical, style linear and creamy white, pedicel cylindrical, filament fleshy, anther elliptic and apiculate at apex, bulblets brownish black, ovary yellowish green, infloresence fastigate at flowering time.

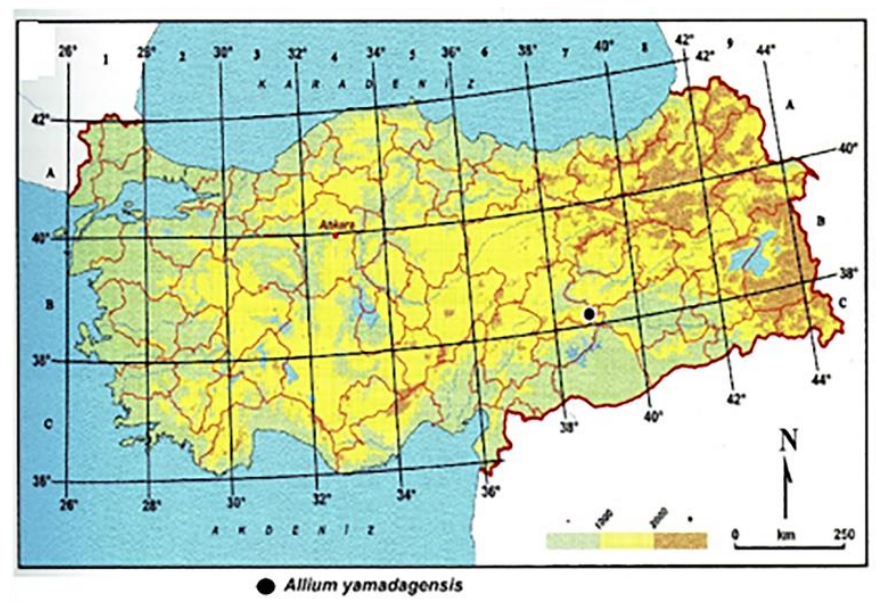

Figure 1. Distribution map of A. yamadagensis
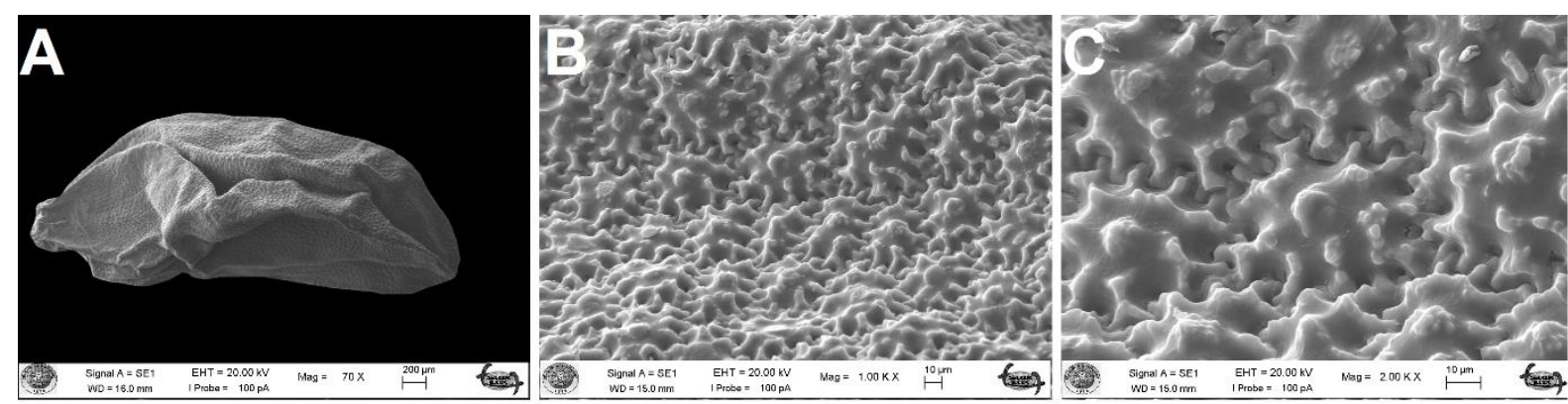

Figure 2. SEM images of A. yamadagensis seeds. A: General view, B: 1000× magnification, C: 2000× magnification 

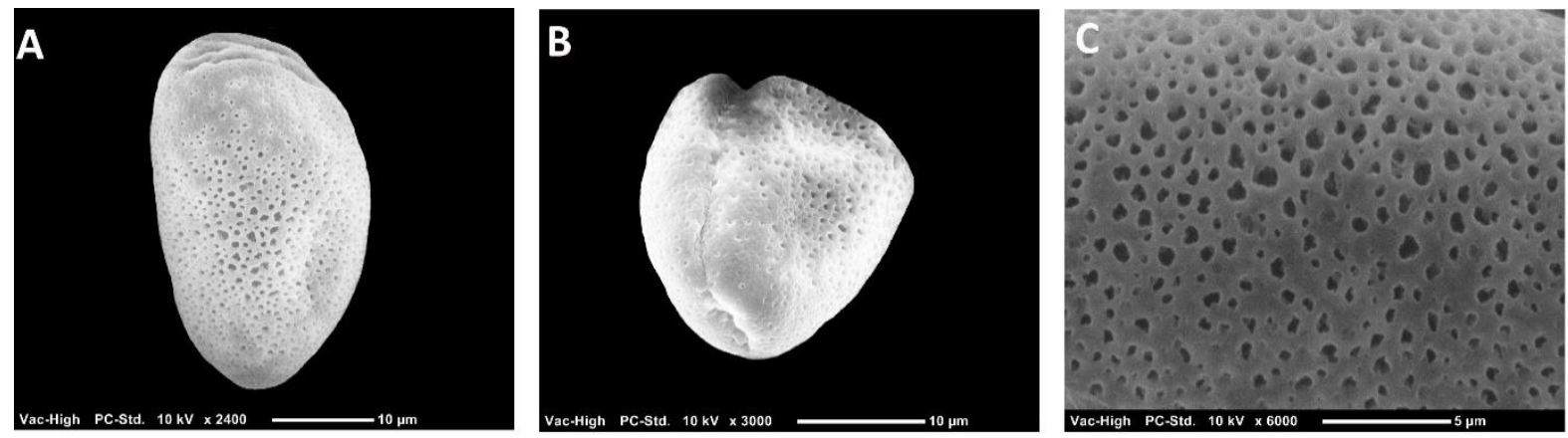

Figure 3. SEM images of A. yamadagensis pollen grains. A: General view, B: 3000× magnification, C: 6000× magnification

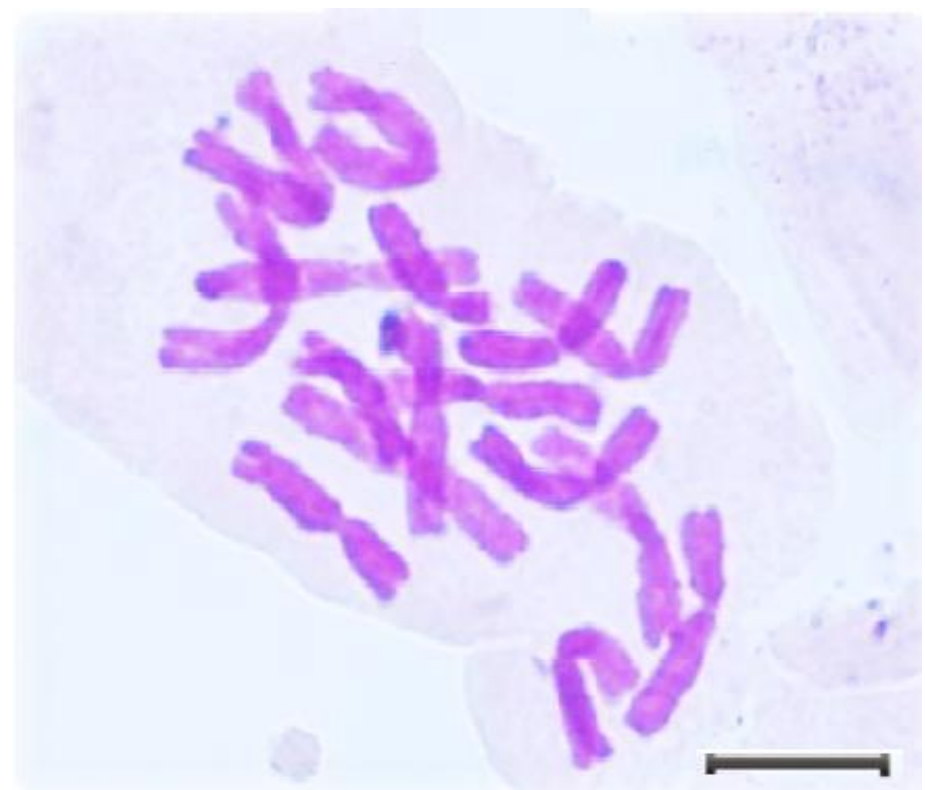

Figure 4. A. yamadagensis chromosomes in metaphase plate $(2 \mathrm{n}=16$, scale bar $=10 \mu \mathrm{m})$

Seed morphology of A. yamadagensis as follows: Seed length 3.5-3.8 mm, seed width 1.5-1.6 mm, L/W Ratio 2.35, seed shape ovate, dominant shape of testa cells ovate-elliptic, periclinal walls (shape and sculpturing) convex, granulose, many irregularly shaped and sized verrucae, anticlinal walls (position, shape, undulation type) fissured, Omega-like undulated (Figure 2).

The pollen characteristics of taxon are identified. The pollen has offered in Figure 3. They were anisopolar and prolate in figures, with polar axes of $23.65 \pm 0.29 \mu \mathrm{m}$ and equatorial axes of $14.92 \pm 0.33 \mu \mathrm{m}$, with oval outlines in the equatorial axes (Figure 3). They are of monocolpate apertures. Also, the colpus size varies between 22.17 and $26.05 \mu \mathrm{m}$ in length, and between 2.41 and $4.75 \mu \mathrm{m}$ in width. The margins are organized, and the ends are rounded (Figure 3 ). The pollen ornamentation of taxon is foveolate-microreticulate. The lumina consists of polygonal and alveolar cells.

The chromosome number of A. yamadagensis, $2 \mathrm{n}=16$, counted in root tips, is also reported and illustrated (Figure 4).

Table 1. New characters for the examined taxon and their comparison with the descriptions in the protologue

\begin{tabular}{|l|l|}
\hline Characters & $\begin{array}{l}\text { The obtained outcomes from } \\
\text { this investigation }\end{array}$ \\
\hline Scape shape & cylindrical \\
\hline Style shape and colour & Linear, creamy white \\
\hline Pedicel shape & cylindrical \\
\hline Filament & fleshy \\
\hline Anther shape & elliptic, apiculate at apex \\
\hline Bulblets colour & brownish black \\
\hline Ovary colour & yellowish green \\
\hline Inflorescence & fastigiate at flowering time \\
\hline
\end{tabular}




\section{Conclusions and discussion}

A. yamadagensis is morphologically similar to A. sintenisii and differs from it by smaller perigones, scabrid pedicels, loosely bearded and scabrid inner tepals, exserted stamens and scabrid ovary surfaces [6]. The results obtained from morphological studies were consistent with description given in the protologue [6]. Our results allowed to expand the morphological description of some parts (scape, bulblet, style, pedicel, filament, anther and ovary) or to give data for the first time (palynology, micromorphology and karyology) (Table 1). [22] referred from chromosome numbers belonging to seven taxa in the section Allium (subg. Allium). All of them have $X=8$ base chromosome numbers similar to A. yamadagensis. A. heldreichii Boiss., A. scorodoprasum subsp rotundum (L.) Stearn, A. sativum L and A. sphaerocephalon $\mathrm{L}$. are at the same ploidy level (diploid) with A. yamadagensis. Conversely, A. ampeloprasum $\mathrm{L}$., A. margaritaceum Sibth, and A. porrum L. are tetraploid. Otherwise, [21] studied 19 species belonging to Allium L. sect. Melanocrommyum Webb et Berthel from Turkey. Similarly, they established same chromosome number $(2 n=16)$ in 18 species, only A. cyrilli Ten. was tetraploid with $2 n=32$.

Seed morphology studies belonging to subgen. Allium sect. Allium as follows: [5] two species (A. aybukeae H. Duman \& Eksi and A. bilgili H.Duman \& Eksi) and [23] one species (A. porrum L.). Seed measurements and morphology of $A$. yamadagensis mostly support these studies.

\section{Acknowledgements}

The specimens were collected during the field trips for a project supported by a grant from Scientific Investigation Project Coordinator of Selçuk University (Project No: 18401090).

\section{References}

[1] Friesen, N., Fritsch, R.M. \& Blattner, F.R. (2006). Phylogeny and new intrageneric classification of Allium (Alliaceae) based on nuclear ribosomal DNA ITS sequences. Aliso, 22, 372-395.

[2] Herden, T., Hanelt, P. \& Friesen, N. (2016). Phylogeny of Allium L. subgenus Anguinum (G. Don. ex W.D.J. Koch) N. Friesen (Amaryllidaceae). Molecular Phylogenetics and Evolution, 95, 79-93.

[3] WCSP (2016). World checklist of selected plant families. Facilitated by the Royal Botanic Gardens, Kew. Available at: http://apps.kew.org/wcsp/

[4] Kollmann, F. (1984). Allium L. In: Davis PH (ed) Flora of Turkey and the East Aegean Islands, vol. 8. Edinburgh University Press, Edinburgh, pp. 98-210.

[5] Duman, H., Ekşi, G., \& Özbek, F. (2017). Two new species of Allium L. sect. Allium (Amaryllidaceae) from Turkey. Plant systematics and evolution, 303(9), 1271-1291.

[6] Ekşi, G., \& Yildirim, H. (2019). Allium yamadagensis (Amaryllidaceae) a new species from Turkey. Phytotaxa, 400(1), 31-36.

[7] Celep, F., Koyuncu, M., Fritsch, R. M., Kahraman, A., \& Doğan, M. (2012). Taxonomic importance of seed morphology in Allium (Amaryllidaceae). Systematic Botany, 37(4), 893-912.

[8] Karaismailoğlu, M.C., Şık, L., Çiftci, A., \& Erol, O. (2018). Seed structure of some taxa of the genus Crocus L. (Iridaceae) series Crocus. Turkish Journal of Botany, 42, 722-731.

[9] Bothmer, R.V. (1974). Studies in the Aegean Flora. XXI. Biosystematics studies in the Allium ampeloprasum complex. Opera Botanica, 34, 1-107.

[10] De Wilde-Duyfjes, B.E.E. (1976). A revision of the genus Allium L. (Liliaceae) in Africa. Mededelingen Landbouwhogeschool Wageningen, 76(11), 1-237.

[11] Pastor, J. (1981). Contribucio'n al estudio de las semillas de las especies de Allium de la Peninsula Ibérica e Islas Baleares. Lagascalia, 10, 207-216.

[12] Kruse, J. (1984). Rasterelektronenmikroskopische Untersuchungen an Samen der Gattung Allium L. Die Kulturpflanze, 32, 89-101.

[13] Kruse, J. (1986). Rasterelektronenmikroskopische Untersuchungen an Samen der Gattung Allium L. II. Die Kulturpflanze, 34, 207-228.

[14] Kruse, J. (1988). Rasterelektronenmikroskopische Untersuchungen an Samen der Gattung Allium L. III. Die Kulturpflanze, 36, 355-368.

[15] Kruse, J. (1994). Rasterelektronenmikroskopische Untersuchungen an Samen der Gattung Allium L. IV. Feddes Repertorium, 105, 457-471.

[16] Ilarslan, H. \& Koyuncu, M. (1997). Türkiye'de yetisen bazi endemik Allium (sogan) türlerinin tohum morfolojileri. Ot Sistematik Botanik Dergisi, 4, 99-116.

[17] Fritsch, R.M., Kruse, J., Adler, K. \& Rutten, T. (2006). Testa sculptures in Allium L. subg. Melanocrommyum (Webb \& Berth.) Rouy (Alliaceae). Feddes Repertorium, 117, 250-263. 
[18] Uysal, T., Bozkurt, M., Tugay, O., Ertuğrul, K., Şimşek Sezer, E. N., \& Köse, Y. B. (2017). Karyomorphology of Turkish species in Centaurea sections Centaurea and Phalolepis (Asteraceae) and implications for taxonomy. Plant Biosystems-An International Journal Dealing with all Aspects of Plant Biology, 151(6), 949964.

[19] Simpson, M.G. (2006). Plant systematics. Oxford: Elsevier Academic Press.

[20] Barthlott, W. \& Ehler, N. (1977). Raster-Elektronenmiskroskopie der Epidermis-Oberflächen von Spermatophyten. Tropische und subtropische Pflanzenwelt, 19, 1-105.

[21] Genç, İ., Özhatay, N., \& Cevri, M. (2013). A karyomorphological study of the genus Allium (sect. Melanocrommyum) from Turkey. Caryologia, 66(1), 31-40.

[22] Ohri, D., Fritsch, R.M., \& Hanelt, P. (1998). Evolution of genome size in Allium (Alliaceae). Plant Systematics and Evolution, 210(1-2), 57-86.

[23] Lin, C. Y. \& Tan, D. Y. (2017). Seed testa micromorphology of thirty- eight species of Allium (Amaryllidaceae) from central Asia, and its taxonomic implications. Nordic journal of botany, 35(2), 189-200. 